\title{
LITURGY AND LIFE? ON THE IMPORTANCE OF WORSHIP FOR CHRISTIAN ETHICS
}

\author{
Dirkie Smit \\ University of the Western Cape
}

\section{Abstract}

In a first section the author argues that 'seeing' is of fundamental importance for ethics. In a second section he concludes that Christian worship is therefore important for Christian ethics, since Christian worship is one of the social locations where Christian believers learn to see, 'to look in the right direction'. In a third section, he provides a brief answer to the question why this is the case, making comments on the nature of Christian worship, in particular the experience of time and history during worship. In a fourth section, he draws on recent studies on the public role of Christian liturgy to argue that Christians learn to see 'the world' in a specific way during Christian worship. In a concluding section he reminds readers that Christian worship often fails this calling. He continuously refers to South African examples.

\section{Agere sequitur videre}

A shabbily dressed elderly man has come to consult the professor of philosophy with a question about business ethics. "Me and my partner, we have a confectionary store in the Bronx. Last week in comes a young man, very distracted, probably in love, asks for a package of cigarettes. Staring dreamily at the ceiling, he puts down a $\$ 10$ bill, takes his cigarettes and starts out of the store, leaving his change on the counter. Now, Professor, comes a question, business ethics. Should I or should I not tell my partner?'

With this story, Gilbert Meilaender illustrates the importance of vision for ethics, of what we see for who we are and what we do. The moral dilemmas we perceive, he says, depend upon the persons we are. Recognition depends upon character. What duties we perceive - and even what dilemmas - may depend upon the virtues that shape or fail to shape our vision of the world (Meilaender 1986:9).

It is, therefore, not surprising that several well-known Christian ethicists have recently argued that Christian ethics depends fundamentally on seeing, on perception. 'Seeing the world sub specie Christi is the paramount theological activity for Christians,' Dietrich Bonhoeffer already claimed (1959:7-8).

In his seminal analyses of the process of ethical decision-making, the influential former Heidelberg-ethicist and Bonhoeffer scholar, Hans-Eduard Tödt, for example consistently emphasized that 'seeing' constitutes the first of the six major aspects of this process (Tödt $1977,1988 \mathrm{a}, 1988 \mathrm{~b}, 1988 \mathrm{c}$ ). It is not surprising that Johannes Fischer, in describing 'seeing' (Wahrnehmung) as the main task of Christian ethics (as Proprium und Aufgabe christlicher Ethik), discusses Tödt's ethics as such a form of Wahrnehmungsethik (Fischer 1989). A number of South African scholars have recently appropriated Tödt's ideas in their discussions of the process of ethical decision-making (De Villiers 1978; Damon 1995; Mouton 1995; De Villiers \& Smit 1995; Smit 1996) and emphasised the importance of 'seeing' for ethics.

One of the painful experiences of apartheid South Africa was, of course, the fact that we did not 'see' in the same way. Frank Chikane's well-known address to the 1990 Rustenburg Conference, 'Understanding the South African reality' made that very clear (Chikane 1991), 
but most South Africans know this only too well. We lived in so many different worlds and perceived life, reality, history, our society, other people, one another, in radically diverse ways.

The relevant point in this regard is, of course, that we therefore also saw so-called ethical issues in these radically different ways. Even what we regarded as ethical problems, as ethical dilemmas, as ethical challenges differed dramatically. One only has to reread some of the minutes of the different church committees dealing with doctrinal and moral issues during the apartheid years (in the Reformed tradition, e.g. the reports of the kommissies vir leer en aktuele sake, or the reports on openbare sedelikheid), or look again at the courses in theological ethics taught in many seminaries and faculties over the past decades, to become deeply impressed - if not depressed - by the importance of what we saw and what we did not see as ethical challenges.

We have obviously also disagreed with regard to the proper responses to our ethical challenges and with regard to the proper solutions to our ethical dilemmas. However, even before we disagreed about responses, solutions and courses of action, we disagreed fundamentally about what we saw or failed to see, what we experienced and accepted as ethical challenges and what we ignored or overlooked (see also De Villiers \& Smit 1994 and 1996, on differences in South African ethics).

In a very interesting little study on moral indifference, Sins of omission, S Dennis Ford also underlines the importance of seeing for ethics (Ford 1990). He is concerned with 'the absence of moral action rather than with overt expressions of evil' (1990:8). He is convinced that '(o)rdinary folks, as well as philosophers, make what we view as 'mistakes' not through malice, but because they see the world in a particular way' (1990:8). The most persistent problem about ethics, he says, is that most people could not care less. This 'mystery of our own indifference' is for him the beginning point of ethics (1990:11). As a preliminary definition of indifference he formulates that 'indifference is the failure either to see, to acknowledge, or to act on behalf of others' (1990:12). Before one reaches the third part of this definition, the deliberate decision or act of the will not to act, he argues, less self-conscious steps intercede: 'I may remain indifferent because I fail to see that a problem exists; I may remain indifferent because I do not see that a wide disparity between rich and poor, the haves and the have-nots, constitutes a moral as well as economic problem. Without information and knowledge about what is going on (the is) or without a sense that things should be different (the ought), I remain blind and thus ultimately indifferent to the fate of others' (Ford 1990:12).

For these and similar reasons, it has in recent years again become popular in ethical circles to claim that agere sequitur esse, what we do follow from who we are. This has led to a renewed interest, also in Protestant circles, in an ethics of being, of character, of identity and formation, of virtue.

It is therefore not surprising that such a language of an ethics of being, of community, of character, of narratives, of saints, of disciples, and of friends, is already becoming increasingly popular in South African ethical circles as well. This is certainly reflected in local scholarly ethical work over the past decade. N J Richardson completed his doctoral studies on the nature and role of the church in Hauerwas' ethics (1986). In his thesis, Verhaal en moraal ('narrative and morality'), Robert Vosloo (1994) focuses on Hauerwas' narrative ethics and argues for the importance of stories, role-models, heroes, martyrs, saints in Christian ethics. In his doctoral thesis, Discipleship as transformation? Towards a theology of transformation, Russel Botman (1993) develops a black theological perspective and argues for the importance of discipleship and transformation in the construction of a new society. The central question of a theology of transformation, according to Botman, is 'the 'who?' question': 'Who is the responsible person 
in South Africa today?' In his doctoral thesis, Die geloofwaardigheid van die kerk ('the credibility of the church'), Carel Anthonissen (1993) contrasts Bonhoeffer's and Berger's notions of credibility and, in an ecclesial approach to ethics, argues for communities of fellowship, integrity, friendship, and responsibility. And in their doctoral theses soon to be completed, Nico Koopman (1996/1997) and De Wet Strauss (1996/1997) are, respectively, investigating the relationship between virtues and works (Deugde of dade?) and the importance of the church for faith and ethics (' $n$ Kerk om in te glo).

It is immediately clear that these theses have much in common. They share a common moral language, namely the language of an ethics of being, rather than an ethics of doing; the language of saints, the language of community, the language of discipleship, the language of friends (see also H R Botman 1995; and N Richardson 1994). And this is indeed an important point to stress in South African Christian ethics. It is in communities of character that responsible people are to be formed. The challenges facing our society on our way to the $21 \mathrm{st}$ century can definitely only be faced in terms of an ethics of being, an ethics of role models and inspiring characters, an ethics of commitment and responsibility, an ethics of mutual acceptance and living with the other (see also the very instructive analysis by Wuthnow 1991). We have a new South Africa. We now need new South Africans. A good constitution will not be enough. We need a good citizenry, transformed people in a civil society. Agere sequitur esse.

Several other essays in this volume will deal with these aspects in more detail.

It is, however, also possible to change the slogan slightly and to claim that agere sequitur videre, what we do follow from what we see. ${ }^{1}$ To make this simple but fundamental point is the focus of the present paper. This, in turn, leads to the question how and where do we learn to see?

\section{2. 'In worship we are busy looking in the right direction ...'}

In his very valuable study Transformed judgment. Toward a Trinitarian account of the moral life, L Gregory Jones proposes that 'the activity of moral judgment is inextricably tied to particular social contexts and is decisively affected by the presence or absence of theological convictions of some sort or another' (Jones 1990:2). His study is an extended argument to defend this thesis, built around the conviction that Christian life is about learning to live in relation to the mystery of the Triune God (1990: 73-120). This learning occurs through what he calls 'pedagogies of discipleship,' including specific kinds of friendships and specific kinds of practices, according to Jones (1990:121-159). ${ }^{2}$

At the heart of this learning process of transformation in moral judgment is the exceedingly difficult task to see and describe the world rightly.

1 The well-known distinction between seeing, judging, and acting also underscores this. When Duchrow and Liedke, for example, describe the purpose of their valuable ethical study on Shalom. Biblical perspectives on creation, justice and peace (1989), they say that 'The aim of this book is to help congregations, groups, synods, and everyone else: 1) to learn to see the causes and mechanisms of the destruction of justice, peace, and creation, and the alternatives; 2 ) to learn to judge in the light of the Bible what God says and does in and to our situation and what God invites us to share ... 3) to learn to act through the gift of church renewal' (1989:10-11). Before we can judge and before we can act, we must learn to see ...

2 In his instructive and moving recent study, Embodying forgiveness (1995), Jones applies these ideas to the Christian virtue of forgiveness. He argues that the church should be a community 'embodying forgiveness'. He characterizes the Christian God as the Triune God who forgives and who, through the Spirit, transforms a community to become 'a trinitarian community ... practising forgiveness'.

3 This again accords with Ford's ideas about moral indifference: '(I)ndifference is a social, transpersonal 
Accordingly, if we want 'to learn to care in a culture of indifference' (see Wuthnow 1995), we must have social contexts where we learn to see and learn to care, we must be involved in 'pedagogies of discipleship,' in specific kinds of friendships and specific kind of practices, like regular worship together with others.

This, therefore, suggests at least one possible reason why Christian worship is so crucially important for Christian ethics. Christian worship, many ethicists are of the opinion, is one of these 'social locations', perhaps one of the most important places and occasions where Christian believers learn to see. ${ }^{4}$

Green en Bonhoeffer ${ }^{5}$ In Christian worship, we experience specific kinds of friendship (or community), and we participate in specific kinds of practices.

Christian worship teaches us to look in the right direction, explains Stanley Hauerwas. '(E)thics is first a way of seeing before it is a matter of doing. The ethical task is not to tell you what is right or wrong but rather to train you to see. That explains why, in the church, a great deal of time and energy are spent in the act of worship: In worship, we are busy looking in the right direction' (Hauerwas 1989:95).

Hauerwas has been arguing for the importance of vision and therefore of Christian worship over several decades. In his seminal Vision and virtue (1974) he already emphasized the crucial role of this linkage. 'Moral life involves learning to see the world through an imaginative ordering of our basic symbols and notions' (Hauerwas 1974:2). 'The moral life is fundamentally the life of vision, for the task is to see accurately the nature of the world, self, and others without illusion' (1974:2). Against the so-called standard versions of ethics in modern liberal societies, he affirmed: 'The great social task of the church is to become a community where symbolic discourse is used and embodied in ritual and practice because of

phenomenon. Persons do not individually decide to remain indifferent; they are indifferent because they have - as participants in their culture and local communities - inherited ideas, rituals, mythologies, stories, and methods that foster or legitimize indifference rather than commitment. We acquire indifference in the same way that we acquire language: unself-consciously, without deliberation or malice, almost innocently' (Ford 1990:13).

This is not the same as the claim that the primary function of the Christian liturgy is to teach us to see. That would be a grave misunderstanding of the argument of this essay. A proper (Reformed) theology of worship would, however, be necessary to make this clear. At least in the Reformed tradition, since Calvin himself, it has been customary to give preference for the ear over the eye as the primary human instrument for knowing, including knowing God. This was particularly important in the Reformed understanding of worship. A bias for the visible and palpable significantly shaped medieval theology and spirituality. The ultimate religious experience was to be a beatific vision. In this, Calvin brought a major change. We are blind, he repeated. We cannot see. Therefore God speaks to us, and we hear before we can see. And in the worship service, the living God is speaking to us. We hear, and only then do we see. "The medieval Christian longed for the full vision of God. The Reformed Christian longed for the full coming of the kingdom of God. The medieval Christian sought to approach God ... The Reformed Christian sought to respond to the acting God. The Roman tradition tried to see God; the Reformed, to hear God. Their contrasting liturgies are manifestations of these contrasting visions of what it is that we and God have to do with each other' (Wolterstorff 1992:291). This fundamental conviction had very concrete liturgical implications. Describing the Calvinist sense of worship, Maxwell says: 'The really far-reaching change, however, was to say the whole service in a clear audible voice and in the vernacular tongue ... Now, for the first time, the people both heard the words and understood them' (Maxwell 1986: 458).

Still, Calvin himself also explained that, in hearing, we learn to see. This was, therefore, also the way he understood the function and the authority of the Scriptures. They become the glasses, the spectacles, so that we can see. 'The Scriptures are not something to look at but rather look through, lenses that refocus what we see into an intelligent pattern' (Green 1989:107, discussing Calvin). And it is primarily in the worship service where we listen to and hear God's Word, which then helps us to see properly.

Perhaps, in order to avoid such a misunderstanding, it could therefore have been better to claim: Agere sequitur esse. Sed esse sequitur videre. Et videre sequitur audire. 
its assurance that God has indeed redeemed the world in Jesus Christ' (1974:8).

Of course, Hauerwas is not alone in stressing the importance of worship for Christian ethics. Since Tertullian's famous dictum that the Lord's Prayer is a brevarium totius Evangelii, i.e. a summary of the whole gospel, incorporating everything Christians believe and everything Christians should become, do, and be (see Luz 1985:337, 339), many voices have repeated this fundamental conviction. Especially interesting has been the Wirkungsgeschichte of the equally famous dictum from the fifth century, lex orandi lex credendi. This has often been interpreted to show the close relationship between prayer, or worship, and life, or ethics. ${ }^{6}$

In twentieth century Protestantism, Karl Barth - in a paradoxical way, since he is often quoted as showing little interest in the practical detail of the liturgy - is regularly called upon as a major witness in this regard! Still, even if he is not the only one, Hauerwas has certainly

6 The expression comes from Prosper of Aquitaine in the 5th century, ut legem credendi lex statuat supplicandi, as people worship, so they believe.

Klaus-Peter Jörns, practical theologian and former editor of the influential Göttinger Predigtmeditationen, has also suggested the axiom lex orandi - lex credendi - lex convivendi as paradigm for the renewal of the Christian church, Christian life, theology, education and training (Jörns 1988b). In the past decades, several people have in fact suggested similar additions, e.g. lex orandi - lex credendi - lex amandi (Hahn 1956), to include the element of service and love, or lex orandi - lex credendi - lex agendi (T Berger 1985), to include the element of life and ethics. Jörns, in an earlier draft (1988a), added lex vivendi, to relate the whole of Christian life to liturgy and faith, following Wainwright in intimately joining the triad of worship, doctrine and life, but his last suggestion, replacing lex vivendi with lex convivendi, following Huber, Ritschl and Sundermeier's description of an ecumenical life-style (1986) is even more comprehensive. It underlines the fact that the ways Christians worship, the ways they believe and the ways they live together, as faith-community but also in and with the wider community, are, no, ought to be closely related, ought to influence one another, ought to be 'laws', prescriptions, rules for one another. Convivendi can refer to saam-leef but also to same-lewing. As a matter of principle (lex), Christian worship, Christian faith and Christian saam-leef in the samelewing ought to be radically interrelated. For the lex orandi-lex credendi principle in ecumenical work, see Meyendorff 1991; Lathrop 1995.

7 Already in his early and seminal study on Anselm, Barth gave an indication of the importance of faith and prayer for theological reflection. And in the lectures on ethics from the same period he made the same point (Barth 1981b). In the Church Dogmatics, already since the first volume, he developed this fundamental conviction systematically. Bromiley could, therefore, remark that one of the unappreciated aspects of the $C D$ is the ultimate orientation of theology to worship (Bromiley 1979:249). Although Wainwright, looking for the places where Barth explicitly dealt with worship, would remark: 'Unfortunately, in the $C D$ the places are all too rare in which Barth develops his theology of worship' (1986a:179), he also acknowledged that Barth early confirmed him in his own theological perspective and method. In Barth's influential publications on the relationship between church and state, he would show that prayer negates itself if it does not become action - although Wainwright would again comment: "appeal to the liturgical life of the church and its significative function would have strengthened Barth's argument in another small writing that early influenced me and that I still consider to set the right perspective for Christian engagement in social and political life' (Wainwright 1986a, referring to Christengenmeinde und Bürgergemeinde, 1946; for a detailed analysis of these documents by a Southern African theologian, see Horn 1987). In his 1937-1938 Gifford-lectures on the knowledge of God and the worship of God in the Reformed tradition, Barth distinguished - but failed to relate convincingly (see the criticism in Wannenwetsch 1996) - different forms of the service of God, including the worship of the Christian life, the worship service, and the so-called political worship (Barth 1938). He now presented the liturgical assembly as 'the concrete center' of the church's life, and claimed: 'The church service is the most important, momentous and majestic thing which can possibly take place on earth ... ' Duncan Forrester comments: 'When Karl Barth published his Gifford lectures ... some English-speaking readers were surprised to discover, in a book which they assumed was about the relation between theology and ethics, substantial discussions of the cultic service of God (Gottesdienst) alongside the treatment of the political service of God' (1995:149). In The humanity of God (1960) he explicitly endorsed the lex orandi, lex credendi-principle: 'It is imperative to recognize the essence of theology as lying in the liturgical action of adoration, thanksgiving and petition. The old saying, lex orandi lex credendi, far from being a pious statement, is one of the most profound descriptions of theological method' (1960:90). Since the introduction to evangelical theology (1963), Barth would make it very explicit that the first and basic 
done more than most to popularise and to develop these ideas. In fact, Hauerwas has recently illustrated these convictions in a very interesting and explicit fashion. In an essay called 'The liturgical shape of the Christian life: Teaching Christian ethics as worship,' he explains how he has been teaching the basic course in Christian ethics at the Divinity School of Duke University, Durham NC (Hauerwas 1995:153-168). Together with a colleague, he designed the full course shaped around worship. 'The course embodied the presumption that there is literally nothing more important for the Christian people to do than praise God' (1995:154). The ethical task, he claims, is to assemble reminders from the training we receive in worship that enable us to rightly see the world and to perceive how we continue to be possessed by the world (1995:156). He then explains how the course is organised around each of the basic movements in the Christian liturgy, 'from gathering to sending forth' (1995: 156-163).

Unfortunately, this is not the place to enter into dialogue with Hauerwas and to learn from these challenging and inspiring suggestions. There can, however, be no doubt about the fact that South African theologians teaching basic courses in Christian ethics could benefit a lot from following this lead.

\section{3. 'Thinking our way into God's world'}

But why? Why is worship so important for teaching us to see, to look in the right direction? Because of what is supposed to take place in Christian worship, one could argue. But what is that?

This is obviously not the place to enter into a theology of worship. The twentieth century has experienced liturgical movements and renewals in almost all confessional traditions and communities (see e.g. the overviews in Chandlee 1986; Berger 1991; Fischer 1991). As a result, a flood of excellent studies on the nature of Christian liturgy and worship have been published, in recent years, focusing on many different aspects of Christian worship. ${ }^{8}$ There have been many causes for this renewed interest in worship and liturgy, also in Protestant circles. ' Whatever the causes and influences, however, we have experienced a flood of literature on worship, liturgy and theology (for technical distinctions between worship and liturgy, see e.g. Saliers 1984:16-17).

Depending on one's theology of worship, and one's views on what takes place in Christian liturgy and worship, the relationship between worship and ethics can be described in many different ways. ${ }^{10}$

act of theological work is prayer (1963:160). Faith and ethics flow from prayer. Finally, and extremely important, one should remember the way he summarized the proper response to the gospel as prayer, as calling on God, and then interpreted the first petitions of the Lord's Prayer in such a moving and powerful way, also with regard to ethics in The Christian life (1981a). Indeed, to clasp hands in prayer, according to Barth, is the beginning of an uprising against the disorder of this world. It does not surprise one that Saliers devotes a central and excellent chapter in his study on worship to 'a conversation with Barth' (Saliers 1984: 69-84). Unfortunately, this is also not the proper place to investigate the relationship between worship and ethics in Barth's thought (for an informative comparison of Barth and Hauerwas on the importance of ecclesiology in general for ethics, see Hütter 1993.)

8 See e.g. the valuable overviews on the sociology of worship, in Newton 1986, or the theology of worship, Wainwright 1986b; or the informative works by Davies 1986, or Jones, Wainwright, and Yarnold (1978).

9 In his excellent work, Don Saliers (1984) acknowledges that the fountainhead for many ... working on the relations between Christian liturgy and theology remains Alexander Schmemann, the American Russian Orthodox theologian, whose book Introduction to Liturgical Theology opened a new theological world to (me) and many others' (Saliers 1984:13).

10 A few examples. The World Council of Churches has emphasised the liturgical elements of affirming, resisting, and committing, and to make that concrete, they used the categories of remembering, professing, repenting. 
At least one very suggestive way of answering the question why worship is so important for ethics, however, in addition to many other possibilities, is to consider what some people call die Ungleichzeitigkeit der Religion in Christian worship. This refers to the fact that Christian worship has to do with time, with a combination of remembrance, hope, and experience. In worship, Christians remember. Because of that, they hope. And because of that, they are changed, transformed, in the present.

It is not possible to argue here for the central place of such an experience of time in religion, and specifically in Christian worship and ethics. Many scholars have made contributions in this regard, from different perspectives, traditions, and even academic disciplines. ${ }^{11}$

renouncing, and opening, see Niles 1992. According to Westland (1985) Van Ruler used four categories to explain the relationship between the service of God in worship and in the world, namely verdichting, training, paradigma, and uitgangspunt (1985:32-33). Yoder uses 'five underlying practices' which, according to him, are described in the New Testament, particularly by Paul, and which "concern both the internal acitivities of the gathered congregation and the ways the church interfaces with the world' (1991:34). All five, therefore, provide a link between ecclesiastical practice and social ethics that is usually undervalued or ignored, says Yoder. These practices are 'fraternal admonition, the universality of charisma, the Spirit's freedom in the meeting, breaking bread, and introduction into the new humanity' (1991:34-39). From each of these, he then draws implications for ethics (1991:40-44). I have recently also related aspects of Christian worship to ethics in different ways, focusing on the elements of subversion, transformation, calling, and fellowship (see Smit 1995; 1996b; and 1996c) and arguing that one should not for one moment underestimate the crucial social importance of these apects of Christian worship. As moments of subversion, as events of transformation, as experiences of calling, as learning places of living-in-community, Christian worship services play an enormously influential role in society. One can only wonder how many people involved in civil society in South Africa have been formed and inspired in religious households and families and in worshipping religious communities, and how much poorer we would have been without these people.

11 See e.g. the excellent historical and systematic overview on 'Gott und Zeit', in Dalferth 1994; the valuable collection of essays on 'Religion und Gestaltung der Zeit', Georgi et al 1994; and Buxton on the sanctification of time, 1986. Two well-known and authoritative witnesses can suffice as reminders of this widespread opinion, namely James Gustafson and Geoffrey Wainwright.

In his epoch-making sociological study of the church 'as a human community,' Treasure in earthen vessels (1976), the respected and influential ethicist James Gustafson already explained the role of worship in the church's life in terms of its nature as a community of memory and understanding. 'Common memory makes possible common life ... The community keeps its common memory alive by continually rehearsing the important events of its history. The reading of the Bible is one means by which Christians understand and relive the past. The Christian Year in the worship life of the community is a dramatic presentation of the history of the most significant events surrounding Jesus Christ: Advent as the expectation of his coming to rule, Christmas as the celebration of his birth, Lent as preparation for the rehearsal of the events of his Passion, Death, and Resurrection (Gustafson 1976:73-74). From his later work in Christian ethics, it would become clear how important these categories are to his thinking (see e.g. Gustafson 1988).

And as is well known, the internationally renowned ecumenical theologian, Geoffrey Wainwright, develops the whole of Christian doctrine and life, a complete systematic theology, from the perspective of worship and liturgy in his Doxology (1980). 'Worship is ... the point of concentration at which the whole of the Christian life comes to ritual focus ... If the word liturgy is allowed to retain from its etymology the sense of 'the work of the people', it hints at the focal place and function which I ascribe to worship in the Christian life as a whole. Into the liturgy the people bring their entire existence so that it may be gathered up in praise. From the liturgy the people depart with a renewed vision of the value-patterns of God's kingdom, by the more effective practice of which they intend to glorify God in their whole life' (Wainwright 1980:8). According to Wainwright, the purpose of all theology is to be 'Towards God' (Wainwright 1981), i.e. to serve worship, and 'the locus of all Christian theology is to be found in worship' (Wainwright 1982; see also 1986a, 1991, 1992). Within this worship, 'time' plays a crucial role, as he explains in his essay on 'Sacramental time' (discussing what he calls ecclesial time, existential time, and cosmic time, Wainwright 1983:120-133). Like Gustafson, Wainwright would use these ideas extensively in his ethical work. 
The relevant point for the present discussion is that Christian ethics needs this experience of time in Christian worship. This is nothing less than the point of departure, the source of life, for Christian ethics.

In an extremely important essay, called 'Erinnerung, Erfahrung, Erwartung. Die Ungleichzeitigkeit der Religion und die Aufgabe theologische Ethik', in a Gedenkschrift for Georg Picht called Die Erfahrung der Zeit, the well-known German social ethicist Wolfgang Huber, present bishop of the German Evangelical Church in Berlin-Brandenburg, explains this with great clarity.

Huber defines the specific task of Christian ethics in this way. 'Theologische Ethik hat ihre besondere Aufgabe darin, die schöpferische Ungleichzeitigkeit des Glaubens im Blick auf die ethische Probleme der Gegenwart zur Geltung zu bringen' (1984:322). The 'noncontemporaneity' of the Christian faith with everyday realities, the distance, the tension, between the Christian faith and the present, makes ethics possible - and necessary. This tension, caused by the distance-in-time, is creative ('schöpferisch'). In this definition of ethics, three dimensions of (the believing community's experience of) time are therefore intimately related with one another. ${ }^{12}$ The reason for this is given in the nature of Christian faith itself. It has to do with tradition (memory), hope (future), and therefore with creative tension (present).$^{13}$ Huber himself has often made use of some of these aspects in his other ethical writings. The same is, however, true of many other Christian ethicists. ${ }^{14}$

Perhaps Canadian theologian Douglas John Hall, in the subtitle of his work on the nature of Christian prayer and on praying the Lord's Prayer, summarises the underlying notion best when he says that Christian prayer or worship is about 'thinking our way into God's world ...' (1987).

In recent years, South African ethical scholars have also drawn attention to this crucial link between the experience of time in Christian worship and ethics. Robin Petersen, in his excellent doctoral thesis from the University of Chicago, Time, resistance and reconstruction:

12 'In einer solchen Aufgabenbeschreibung sind drei Dimensionen miteinander verknüpft: Zunächst zielt Ethik auf den Umgang mit gegenwärtigen Erfahrungen. Sie handelt von der Gestaltung unseres gegenwärtigen Lebens. Doch diese Gestaltung soll - das ist das zweite Element - im Licht einer Erwartung vollzogen werden, die mit dem Neuen rechnet, das aus der Zukunft her auf uns zukommt ... Deshalb hat die Erwartung der Zukunft orientierende Bedeutung für die Mitgestaltung der gegenwärtigen Lebenswelt ... Solche Zukunftserwartungen aber - darin zeigt sich das dritte Element - sind gespeist aus der Erinnerung, nämlich aus der Erinnerung an die schon in der Vergangenheit immer wieder formulierte und in Praxis umgesetzte Erwartung eines Neuen, in Erinnerung vor allem an die exemplarische Geschichte des Jesus von Nazareth' (Huber 1984:321).

13 'Christlicher Glaube trägt wie alle Religion das Moment der Ungleichzeitigkeit in sich. Ihm ist ein Traditionsbezug eigen ... Doch zugleich ist er von einem utopischen Überschuß geprägt, von einem Vorausgreifen auf eine Zukunft, die noch nie da ist und von der keiner weiß, wann sie kommt. Die Kraft der Erinnerung und die Kraft der Hoffnung zugleich konstituieren die Ungleichzeitigkeit der Religion. Diese Ungleichzeitigkeit kann dann schöpferisch werden, wenn sie die Eindimensionalität eines Alltagsbewußtseins durchbricht, daß heute mehr und mehr unter die Gewalt des Konsumismus gerät ...' (Huber 1984:322).

14 One is reminded of Jennings' inspiring work on the complex of guilt, confession, forgiveness, and liberation, as a result of the experiences in Christian worship (Jennings 1988). Dietrich Ritschl's well-known ecumenical ethics also depends on the same point of departure (see Ritschl 1987), as Schobert's thesis on remembrance as a fundamental activity of Christian faith carefully documents and explains (1992). Several scholars have analysed the role of narrative, remembrance and expectation in the constitution of the identity of the acting subject (see e.g. Schaeffler's instructive analysis of the nature of prayer, 1988; Streib 1994; Zerfaß 1988; or even Jüngel 1983). Practical theologian and ecumenist Ernst Lange has written movingly on the church and the worshipping community as the school where believers learn to talk and act, and learn to practise freedom (Lange 1980). James McClendon, in several of his influential major works, develops his ideas along these lines (see e.g. the important McClendon 1989). One could mention a flood of other scholarly works. 
Rethinking Kairos theology (1995), argues that this is the way to understand the liturgy and the religious experience of the African Independent Churches in South Africa and their response to life. Andrew Phillips, in his innovative doctoral thesis on Die nagmaal as ' $n$ paradigma vir Christelike sosiale etiek (1996) explicitly uses Huber's distinctions as a broad framework in order to describe the paradigmatic role of the celebration of the Lord's Supper for Christian social ethics (see also Smit 1996b).

And indeed, when one considers how many Christians regularly attend worship services in South Africa, it is simply impossible to ignore or to underestimate the importance of this for ethics in South Africa (for interesting analyses of the statistics, see e.g. Hendriks 1995a, 1995b, 1996). In a volume like this, on Christian ethics in South Africa, this perspective may simply not be neglected.

However, more must be said. It is not enough merely to claim that Christian worship is important for ethics, since it liberates the worshippers from the givenness of everyday reality and brings them into a creative tension between past, future, and present, so that they learn to look in the right direction. A crucial question remains, of course, namely what the worshipping community sees?

\section{4. 'Holiness joins liturgy and justice'}

In order for Christian worship to have ethical implications, the world, life itself, history, the public sphere, must somehow be present in the liturgy. Christian liturgy has to do with Christian life. Christian worship has ethical implications for public life because the worshippers learn to see the world in a certain way.

There are obviously many different ways of seeing the relationship between Christian liturgy and public life, between Christian worship and the world. In recent years, many scholars have contributed to this discussion, often in radically different and even conflicting ways. ${ }^{15}$

15 The powerful comments during his last days in prison by Bonhoeffer, linking prayer and doing what was right, have, of course, led to a long tradition of reflection. See e.g. Paul Lehmann's deliberate attempt to work that out with regard to worship and liturgy, in Lehmann 1985: 'Politics are the business of liturgy'. For a few other wellknown positions, see e.g. also Searle 1980, with several interesting essays; Jennings 1982, although he concentrates on prayer and praise, this inspiring little book - written for South Africa and dedicated to South Africans! - is full of valuable perspectives on the relationship between worship and life; Volf 1993, attempting to reconcile adoration and action, the perspectives of evangelicalism and social action, in a volume, edited by Carson, with the same theme; and Willimon 1983, a popular book by a pastor and liturgist asking concrete questions about the practical ethical implications of weekly worship, and answering them in Hauerwas-fashion. Thiemann 1991, in an interesting article from a Lutheran perspective, seeks for a way that Christian worship could fulfil its public responsibility in a radically pluralist society. In his doctoral thesis, Westland 1985 compares the positions of Van Ruler, the Van der Leeuw-Stichting, and the Movement Christians for Socialism, and in this process provides valuable material from twentieth century Dutch thought on liturgy and life. From the circles of liberation theology, attention has often been given to worship and to its (potential) social and political implications (for an overview, and for literature, see e.g. Witvliet 1986). In an excellent recent analysis, Wannenwetsch (1996) offers a critique of both a modern (William Temple) and a post-modern (John Milbank) account of church and politics. He then develops his own ideas on the so-called 'implicit' political dimension of Christian worship, explaining how Christian worship can overcome 'the two most important antagonisms with which politics is bound to deal since its invention in Greek antiquity', namely the antagonism between public and private, and the antagonism between the vita activa and the vita contemplativa. He then discusses the 'explicit' political dimension of Christian worship, asking how it relates to the other publics in society and state. He concludes with an example, namely that Christians are 'trained in hearing peacefully' (see also footnote 4 on hearing as primary activity according to a Reformed theology of worship). This is indeed a very informative and challenging essay. 
In South Africa, John de Gruchy has written two major contributions touching on this relationship, namely his introductory essay in Cry justice! on 'Christian spirituality and social transformation' (1986c), and his essay on 'Prayer, politics, and false piety' (1986a) in Boesak \& Villa-Vicencio's When prayer makes news. Both these extremely valuable contributions were written during the years of struggle and resistance against apartheid, and deliberately reflected a prophetic and critical stance. Perhaps it is now possible for South African Christian ethicists to offer more constructive reflections on the public role and function of Christian worship with regard to community building, the formation of character and integrity, the development of virtuous people, etcetera (see therefore also De Gruchy 1994).

Once again, this is not the proper place to enter into these fascinating and extremely important debates. Both South African ethicists and liturgists should, however, concerned themselves with this relationship. ${ }^{16}$

Once again, a single illustration may suffice to show what is possible. One very instructive way to explain this relationship has been offered, over a long range of valuable contributions, by the widely respected Calvinist philosopher Nicholas Wolterstorff, well-known in South Africa. He links liturgy, holiness, and justice in a number of ways. ${ }^{17}$

16 In the short, but inspiring liturgical study by J Müller (1988), there is a chapter on 'Die erediens en die wêreld', but this does not say anything concrete about the relationship. Liturgical works could serve the discussion in South Africa by considering this in more practical detail.

17 In his discussion of the social ethics of - what he calls world-formative - Reformed Christianity, Until justice and peace embrace, Wolterstorff already dealt at length with the importance of worship and liturgy as the distinctive element of Christian existence (1983:146-161), arguing that 'a rhythmic alternation of work and worship, labor and liturgy is one of the significant distinguishing features of the Christian's way of being- in-the-world.' Liturgy, said Wolterstorff, authenticates Christian action in the world.

In several more recent essays, he has explained and developed this point in some detail. In 'Liturgy, justice, and holiness' (Wolterstorff 1989) he starts with the observation that holiness is a preoccupation of the Christian liturgy. Many people, he says, may feel 'that when it comes to holiness we have left behind such earthly, horizontal concerns as justice and entered a higher realm, the realm of the transcendent, of the divine' (1989:12). His argument is that there is no such dichotomy between holiness and justice. 'God's justice is a manifestation of his holiness; our justice is a reflection of God's holiness. When we deal with justice, we are dealing with the sacred. Injustice is desecration. The preoccupation of the liturgy with holiness does not separate liturgy from justice. On the contrary, holiness binds liturgy and justice together' (1989:13).

He starts his argument by noticing that the acknowledgement of God's holiness is inseparable from an imperative for our holiness. Almost no one will dispute that the liturgy is for making us holy, he claims (1989:13). But, he continues, what does holiness mean? In fact, nothing in the language of liturgy and devotion is more alien to our contemporary secular mentality than speech about holiness. 'Once upon a time the concept of holiness was fundamental to the way in which human beings thought about reality and experience. This time - for us at least - is past,' he says (1989:13).

In a major part of his article, he discusses the meaning of holiness by making use of Jonathan Edwards (Religious affections), Rudolf Otto (The idea of the Holy), Karl Barth (the discussion of holiness in CD II/T), and particularly Mary Douglas (Purity and danger). He then turns to the Old Testament, especially Leviticus and Deuteronomy, and concludes: '(l)t is not at all difficult to see why justice is treated as a manifestation of holiness. The unjust society is a society in which wholeness and integrity are lacking. For it is a society where people exist on the margins, on the periphery, hanging on rather than being authentically incorporated into the life and welfare of the community. Such a society fails to mirror the wholeness of God. And when we as Christians recall that this God whose holiness we are to reflect in our lives and our societies is himself a trinitarian community, then it is obvious that the unjust society is an unholy society. It does not mirror God's communitarian wholeness' (1989:18).

In the final part of his article, he moves to the New Testament, and to different forms of brokenness in the world, that we are, 'in one way or another', to embrace as followers of Jesus Christ. This time he depends heavily on Marcus J Borg (Conflict, holiness \& politics in the teaching of Jesus). Borg's thesis is that Jesus initiated a renewal movement within the maelstrom of holiness movements of his time emphasizing mercy as an alternative 
Once again, this represents just one way of arguing for the relationship between liturgy and life, between worship and work. And it is clearly no coincidence that Wolterstorff is from the Reformed tradition and community. Reformed theology has continuously shown a particular preference for issues of justice and transformation (see e.g. H R Niebuhr 1951; Leith 1988; Smit 1996a), and issues of holiness, covenant, and vocation (see e.g. Schuurman 1996/1997). Reformed communities in history often related their Sunday worship with public responsibility and involvement in public, social, economic, and political life. They have often been under the impression that Paul sends the believers in Romans 12:1ff. into the world in order to practice their 'true worship', their real service of God, after having listened to the good news of chapters 1-11, concluding with the major doxology at the end of chapter 11. It is because of this that - the Reformed! - Karl Barth could argue, commenting on this passage in Romans, that one must read both the Bible and the newspaper in order to understand the gospel. ${ }^{18}$

vision. For Wolterstorff this means that, in Jesus, we find 'a radically new understanding of how we are to reflect God's holiness. In Jesus we find, if you will, a new hermeneutic of Torah's concern with holiness ... The holiness of a community resides centrally in how it treats human beings, both those who are members of the community and those outside, even those outside who are 'enemies.' And specifically, the holiness of a community consists .. in the members of the community embracing the broken ones, and working and praying for their healing ... We learn from Jesus that a community which shuns the broken ones can never be a whole community - that is, can never be a holy community. The holy community is the merciful community, the just community' (1989:20). He concludes that God asks us for more than liturgical acknowledgment of God's holiness. 'God asks that we, in our communities, reflect God's holiness, God's wholeness. Jesus, the Son of the Father, showed us what it is to do that. It is to befriend the broken ones and to work for their healing. To do that one must struggle for justice - for the day when all those on the margins have been given place and voice in the community, and when the enemy has been befriended. Holiness joins liturgy and justice. In the liturgy we hymn God's holiness. In lives of justice and mercy we reflect God's holiness. In the liturgy we voice our acknowledgment of God's holiness. In the struggle for justice we embody that acknowledgement' (1989:20).

In a second article, 'Justice as a condition of authentic liturgy', Wolterstorff focuses more explicitly on this relationship between liturgy and justice (Wolterstorff 1991; for responses to his essay, see also Cunningham 1991; Fishburn 1991; and Olson 1991). So often, he says, people find it difficult to see that liturgy, justice, and evangelism are all of crucial importance for being the church. People concerned with one of the three often find it difficult to understand the importance of the other two. This leads, says Wolterstorff, to aberrations (Wolterstorff 1991:6-7). He briefly explains what he means by liturgy and justice (1991:7-9). Almost everyone in the Christian community, he continues, operates with some view on what would deprive liturgical actions of their authenticity. He gives several popular examples (1991:8). Turning to the biblical writings, he argues that there 'the authenticity of the liturgy is conditioned by the quality of the ethical life of those who participate' (1991:8). He discusses several well-known passages from the Old Testament, showing that 'liturgy in the absence of justice does not please God; it nauseates God' (1991:10). This does not mean, according to him, that justice is to displace liturgy (1991:12-14). The relationship for which he wants to argue is rather a 'not/unless point ... not authentic liturgy unless justice' (1991:12). The connection is given, according to him, in the idea of the covenant, where the pattern is: deliverance, obedience, blessing (1991:14). 'The prophetic critique of the cult is grounded in the conviction.' says Wolterstorff, 'that the point of the liturgy is to give symbolic expression to the commitment of our lives to God' (1991:17). Again, he demonstrates that exactly the same ideas are present in the New Testament as well (1991:18-21). 'Worship acceptable to God, authentic worship, is the worship of a pure heart. And the only pure heart is the heart of a person who has genuinely struggled to embody God's justice and righteousness in the world and genuinely repented of ever again doing so only half-heartedly. The worship of such a person consists then of giving voice and symbolic expression to the concerns and commitments of the heart. This ... is the biblical vision' (1991:21); see also 'Worship and justice' (1992b).

18 In fact. Wolterstorff, in his excellent discussion of 'The Reformed liturgy' (1992), points to the remarkable fact that, partly as a result of this view of worship, Reformed people often show a lack of interest in liturgy: 'The liturgy as the Reformers understood and practised it consists of God acting and us responding through the work of the Spirit ... The Reformerd saw the liturgy as God's action and our faithful reception of that action. The governing idea of the Reformed liturgy is thus twofold: the conviction that to participate in the liturgy is to enter the sphere of God acting, not just of God's presence, plus the conviction that we are to appropriate God's action 
Two illustrations of this Reformed tendency to link worship with justice and ethics can suffice, one from South Africa, one from the ecumenical movement.

In the new Church Order of the Uniting Reformed Church in Southern Africa, this becomes clear from the way in which the responsibilities of the local congregation is described in Article 4: "The congregation forms a community of believers in a particular place to serve God, each other and the world. Service of God has a bearing on the whole life of the congregation and therefore includes service to each other and to the world.'

The Article then describes these three related forms of service: 'The heart of this service of God is to be found in the coming together of the congregation round the Word of God and the sacraments. There God is worshipped and praised. His Word is listened to, the sacraments are received and all needs are brought to God in order to strengthen the believers in their faith and to prepare them for their service to each other and the world.'

This worship service, therefore, leads to the second form of service: 'The believers accept mutual responsibility for each other in their spiritual and physical needs. The congregation lives as a family of God in which all are inextricably bound to each other and share each other's joy and sorrow. Each considers the other as higher than him- or herself and no one only cares about her or his own needs, but also about the need of others. In this way they share each other's burdens and carry out the law of Christ.'

And worship leads to the third form of service: 'The congregation's service to humankind and the world consists of proclaiming God's reconciling and liberating acts in and for the world; of living out the love of Christ in the world; of calling humankind to reconciliation with God and mutual reconciliation and peace; of following God, who is in a special way the God of the destitute, the poor and the wronged; by supporting people in any form of suffering and need; and by witnessing and striving against any form of injustice; by calling upon the

in faith and gratitude through the work of the Spirit ... Of course we must keep in mind that it is not only in the liturgy that we are confronted with God acting in love toward us. The liturgy is the continuation of God's action in the world, and, in turn, God's action in the world is the continuation of God's action in the liturgy. In the liturgy we respond in praise and thanksgiving to God's actions in general. So, too, our response to God's action in the liturgy is a continuation of our response in daily life, and, in turn, our response in daily life is a continuation of our response in the liturgy. It should be added that from the beginning it has been characterisic of the Reformed churches to insist that our response of working in the world is not inferior to our response of worshiping in church. Work and worship are but different modes of obedient gratitude ... (1992:290-291) ... This explains the tendency of Reformed people to think of the liturgy as purely instrumental for their work in the world ... If within the liturgy itself little opportunity is given to respond ...it will be almost inevitable that we will think of our work in the world as the totality of our appropriate outward response to God's action in the liturgy ... Then, too, people will shortly begin to think that the only really important thing in God's eyes is our obedient work in the world and will begin to think of the liturgy as the issuing of marching orders. They will see the liturgy as motivation and guidance for what really counts - namely, our work in the world. Sunday will be seen as occurring just for the sake of Monday through Saturday. The integrity of worship as one mode of our response to God will be lost from view. I indicated earlier that in their beginnings the Reformed churches insisted that work is not inferior to worship. In their later days, they have often assumed that worship is inferior to work'(1992:297). This, he says, also explains why Reformed theological training is often not really interested in liturgy, but rather in ethics and in preaching: 'If ... then it will indeed seem odd to pay much attention to the liturgy. We will focus instead on our work in the world - and on training students to preach' (1992:298).

It would be a total misunderstanding to read this essay in such a way that it contributes further to this typically Reformed! - misunderstanding that liturgy should serve life or that worship should serve work. Worship should not be 'instrumentalised' or 'ethicised'. Worship is not inferior to work and ethics, and liturgy is not inferior to life. Precisely for that reason, a proper theology of worship is necessary, to maintain the integrity of Christian worship. It is not without very reason that so many Protestant theologians, including ethicists, have shown how difficult it is to preach the gospel with an ethical thrust, and how tempting but dangerous it is to 'ethicise' theology, worship, and Christianity (for recent comments, see Huber 1996). 
government and the authorities to serve all the inhabitants of the country by allowing justice to prevail and by fighting against injustice; by witnessing against all rulers and those who are privileged who may selfishly seek their own interests and thus control and harm others' (URCSA).

The point is clear. All of this is clearly very Reformed - and the parallels to Barth's Gifford lectures are also obvious. A Reformed theology of worship, a Reformed ecclesiology, and a Belhar-political ethics all inform one another.

A second example. In the ecumenical movement, worship has also played a crucial role in ethical discussions. The link between liturgy and life has been stressed in most recent ecumenical documents on worship (Berger 1991b). In this regard, Reformed Churches, theologians, and theology, have made important contributions. ${ }^{19} \mathrm{~A}$ case in point is the recent appropriation of the (Reformed) notion of covenanting, the appeal to Christians and churches to covenant with one another in collective endeavours to work towards common moral visions and goals, and the role of worship in this process. Biblical ideas on the covenant, propagated by Reformed Churches, have played a major role in ecumenical thought over the past two decades. ${ }^{20}$

In 1990, during the Seoul World Convocation on Justice, Peace, and the Integrity of Creation, organized by the WCC, all churches were called on to make a covenant based on God's covenant for the well-being of God's total creation. The churches were also called to translate their response to God's covenant into acts of mutual commitment within the covenant community. Four areas were selected for specific 'acts of covenanting', namely concrete commitment to work for a just economic order and for liberation from the bondage of foreign debt, for the true security of all nations and people, for building a culture that can live in harmony with creation's integrity, and for the eradication of racism and discrimination, on national and international levels, among all people.

In all of this, worship was regarded as extremely important. Ten Affirmations on Justice, Peace, and the Integrity of Creation were made and expressed in the liturgical rhythm of affirming, resisting, and committing. In order to make this more concrete, the Seoul

19 For an overview of the important role of worship in the ecumenical movement in general, see Berger 1991; or Best \& Heller 1995, for essays on worship in the service of community and unity, and specifically Crawford 1995. Although the ecumenical movement has seen significant developments in the areas of worship and of theology, claim Best \& Heller, what has been missing is the link between these developments. 'In short: the lex orandi and the lex credendi, the 'rule for prayer' and the 'rule for belief, have tended to become separated in the ecumenical discussion, not to mention in the lives of many churches. The vital connection between the two 'rules' has become weak; and the practice of theology and the practice of worship are not nourishing the other as they should' (Best \& Heller 1995: x). Their essays address this situation. They discuss five 'concerns' which call for further ecumenical reflection and action. The second of these is 'the need to develop more fully the relationship of worship to work for justice, witness and service, to the Christian commitment that God's will be done '... on earth as it is in heaven" (1995:xii).

20 During the 1975 Nairobi Assembly of the WCC the Just, Participatory, and Sustainable Society programme was launched. Throughout the many so-called JPSS dialogues, until 1982, "covenant' emerged as a biblical metaphor through which the many concerns were linked. In February 1983 WARC's Executive Committee issued a statement called 'A Covenant for Peace and Justice', suggesting the preparation and summoning of a special ecumenical gathering, under the auspices of the WCC, where all churches could covenant together. Later the same year, the Sixth Assembly of the WCC (1983) indeed decided to make 'Justice, Peace, and the Integrity of Creation' one of the priority areas for all the programmes and activities of the Council: '.. . to engage member churches in a conciliar process of mutual commitment (covenant) to justice, peace and the integrity of all creation ... The foundation of this emphasis should be confessing Christ as the life of the world and Christian resistance to the demonic powers of death in racism, sexism, caste oppression, economic exploitation, militarism, violations of human rights, and the misuse of science and technology.' 
participants entered into a covenant of solidarity. They did this during worship, following the biblical rhythm of remembering, professing, repenting, renouncing, celebrating, and opening, already mentioned earlier. The church responds to the covenant by remembering that God's covenant, which is justice and peace, embraces all of creation; professing our faith in God's promises for justice and peace on earth in its wholeness; repenting of our turning away from God's covenant for justice and peace; renouncing all idols of wealth, power, race and gender superiority and security which cause people to suffer and the earth to be dominated, plundered and destroyed; celebrating God's justice and peace and the mystery of God's creation; and opening our lives to respond in faithfulness to God's covenant with all living creatures, indeed with the earth as a whole.

Again, ethicists in South Africa could certainly learn from these deliberate attempts to bring a conscious ethical element into the Christian liturgy. It could, in fact, help ethicists to make their own work more concrete, practical, and useful. The question how, when and where ethical work impacts on society cannot be ignored. If Christian ethicists want to make a meaningful contribution, they must also consider these questions of vocation. And in answering these questions, considering the crucial role of Christian worship can prove extremely important.

In many South African churches, particularly during the apartheid years, it was customary to develop liturgies with a view to specific ethical issues and challenges, with suggestions for prayers and litanies, scripture readings and sermons, etc. This is an initiative that could be very useful, and that could, in turn, also help churches, congregations, and people involved in regular liturgical activities. For example, theologians like Conradie (1996; also in cooperation with the relevant Committees from the URCSA and the DRC) and Field (1996:270ff) have recently offered valuable liturgical suggestions with regard to ecological issues. An approach like this certainly offers exciting challenges and prospects. In the volumes of the series Woord teen die lig dealing with ethical issues, like peace, justice, and virtues, tentative first steps in this direction have also been made (Burger et al 1990; 1993; 1996).

\section{5. 'Liturgy has been used to prevent the gospel from taking hold'}

It is obvious that only a proper theology of worship could treat the many issues raised in these comments, and perhaps help to avoid the many possible misunderstandings it could cause.

It is not even necessary to acknowledge that the preceding paragraphs are highly idealistic. 'Christian worship has been and still is an ambivalent phenomenon, to say the least' (Witvliet 1991:303). In reality, sadly, our worship is often more a reflection of society, than a critical and creative interruption of society. Sadly, we often legitimate society instead of subverting and interrupting it. We often endorse and celebrate the values and virtues of our diverse societies. We form people according to the expectations of our groups and communities, and not according to the gospel. We bless their ideas of calling and success, we often undermine the last forms of solidarity and community left.

It would be a grave misunderstanding to suppose that all Christian worship is true Christian worship. Precisely for this reason, we need serious theology of worship, also providing critical tools to interpret and evaluate our worship practices.

The Christian Church betrays society when it is no longer the Church and when it no longer worships as the Church. The Christian Church betrays society when it merely becomes a mirror image, a reflection, of everyday life, of reality outside the place of worship.

This betrayal can take many forms. It has, for example, often been pointed out with regard 
to the disastrous effects of secularization on Christian worship. ${ }^{21}$ In modern societies this has become a major temptation for the Christian church. In many ways modernity contradicts every aspect of this fundamental Christian experience of time. Instead of subversion it offers secularization, instead of formation it offers rationalization, instead of calling and a sense of responsibility it offers autonomy, instead of community and solidarity it offers individualism. This is a sad tale.

In South Africa, this betrayal has also taken its own peculiar forms. John de Gruchy discussed some forms of this betrayal in his essay on 'Prayer, politics, and false piety' (1986a). $\mathrm{He}$ argues that false piety takes on many forms, "but it inevitably replaces the God who is beyond human control with a god who can be manipulated to serve and sanction self-interest. False piety reduces God to a deus ex machina at our disposal, a god whom we can use for our own ends and one upon whom we can call to sanctify what is in our best self-interest. The god of false piety takes on the characteristics of the particular race, group, or class to which we may belong, and when we enter into battle this god is undoubtedly on our side' (1986a:98). He specifically discusses 'two interrelated though apparently opposite manifestations of false piety,' namely 'its privatization and its patriotic appropriation by the nation or the state' (1986a:103-112). ${ }^{22}$ In several South African Christian communities and traditions, we may indeed have reason to be self-critical in this respect. ${ }^{23}$

21 In the studies of the World Council of Churches, this has also played a major role (see Davies 1986b). The study by Saliers (1994) and the essay by Huber (1984) are strongly recommended reading in this regard.

22 In De Gruchy's words: 'The life and worship of churches, and the preaching of its pastors, is often determined in practice much more by popular demands than by biblical and theological integrity. If the church becomes a haven of refuge from responsibility in the world, if sermons are geared to massage the spiritual ego and sanction selfinterest, if the liturgy whether traditional or contemporary becomes a mechanism of escape rather than the worship of God as Lord, and if priest, preacher, and people somehow combine or conspire to make it so, then false piety not only flourishes, it becomes the norm' (1986a:105-106).

23 One example. A research project, self-initiated, but done with the assistance of the HSRC, into the Afrikaans religious programmes of the SABC during the late eighties, produced remarkable information in this regard. The full results, as well as a detailed account of the methodology employed, were published elsewhere (see e.g. Müller \& Smit 1991 and 1994; for similar research, see Cilliers 1994).

Seven different kinds of programmes were analysed, representing broadcasts over an 8-month period during 1987. The content of these programmes was analysed from a variety of perspectives, i.a. in an attempt to describe their doctrinal or beliefs-content (lex credendi) and their ethical content (lex convivendi), i.e. their implicit claims to proper convictions and proper conduct.

A list of key-concepts was used in order to describe the content. The result? Concepts dealing with the religious life of individuals completely dominated ('geestelike vernuwing', 'ware godsdiens', 'bekering', 'geloof', 'geloofsekerheid', as well as 'troos', 'vreugde'). Concepts dealing with both church and society were completely absent ('kerk' 1\%, 'meelewing' 5\%, 'sending' 3\%, 'burmhartigheid' 1,5\%, 'versoening' 1,5\%, 'geregtigheid' $2,5 \%$, 'vrede' $1 \%$, 'hoop' $2 \%$ ).

A detailed list of traditional doctrinal categories was used in order to describe the faith-content. The result? The only categories worth mentioning are those of the intra nos, the inner experience of individual religion and perhaps spiritual attitudes ('nuwe lewe', 'toewyding', 'sekerheid van die heil', 'liefde', 'vrugte van die Gees'). Categories dealing with church and society were absolutely and completely absent, including creation, history, anthropology, providence, Christology (person and work of Christ, incarnation, life, parables, miracles, suffering, death, resurrection, ascension, sitting at right hand of God), person and work of the Holy Spirit (except the fruit), election, justification, reconciliation, sin, guilt and forgiveness, the law or commandments, the church ('oorsprong, wese, ware en valse aurd, strydend, eenheid, sigbaar en onsigbaar, kerklike en gemeentelike lewe, ampte, tug, gemeentebou, kerk en owerheid, kerk en sending, godsdiensvryheid, getuienis'), the sacraments, eschatology, the kingdom of God. All of these were not part of the contents of the programmes in any meaningful way at all.

A list of general ethical categories was used in order to classify the ethical thrust of the programmes. Almost $60 \%$ of the programmes had no ethical content at all. The only category worth mentioning is love (13\%), mostly 
'In the end we must admit that it is misleading to speak of the relationship between liturgy and ethics as though there were only one essential linkage. There are a multitude of connections between liturgy as enactment of the story of faith and the lived narratives of our lives ... We cannot explore in detail here the political dimensions of authentic liturgy. But in our world ... we must also admit that the liturgy has been used ideologically and politically by those in power to prevent the gospel from taking hold The long history of abuses of prayer and liturgy in the name of God is worthy of deep lamentation ...' (Saliers 1994:187). But even if the implications of liturgy for life are often negative, they still pose a major challenge to ethicicts, particularly in South Africa.

understood in an individualistic and vertical sense. 'Versoening' $(2,7 \%)$ and 'vrede' $(1,7 \%)$ were next, while 'barmhartigheid', 'solidariteit', 'geregtigheid', 'menswaardigheid', 'eerbied vir lewe', 'vergifnis', 'verdraagsaamheid' were completely absent. Again, values dealing with life-together, convivendi, either in church or same-lewing, were not part of the worship, were not embedded in the Christian story as celebrated in public.

A list of traditional categories, dealing with moral issues, was developed from the Decalogue in order to classify moral topics addressed in the broadcasts. The result? This time, $91 \%$ of the programmes had no reference whatsoever, whether direct or indirect, to any moral issue traditionally dealt with under these wide- ranging rubrics. The only issue worth mentioning was the $3,7 \%$ referring to marriage life. Idolatry was completely absent, as were 'misbruik van die Godsnaam', 'Sondagsheiliging', 'kerkgang', 'gehoorsaamheid aan ouers', 'gehoorsaamheid aan gesag', 'regsorde', 'waarheid', 'burgerlike (on)gehoorsaamheid', 'eerbied vir lewe', 'moord', 'aborsie', 'medies-etiese aangeleenthede', 'seks as gawe of seksuele verwildering', 'eiendom', 'arbeid', 'oorlog', 'vrede', 'politiek', 'mag en onmag', 'menseregte', 'verhouding kerk en staat', in short, all possible subjects related to church and society, to convivendi.

From yet another perspective, scholars in journalism developed a list of the ethical issues that were at the forefront in the public media over the same period of time. This list of burning issues, reflecting the story of the dominant culture at the same time, was then used to see which of those issues were addressed in these public worship services as well. Even the most indirect references, in passing, were counted. The result? The issues were: 'algemene gewelddadigheid, insluitende moord en misdaad', algemene menseregte', 'aanhouding, politieke verhore', 'persbeheer', 'militre geweld, regeringsoptrede', 'reg tot opstand, onluste', 'groepareas', 'diskriminasie, byvoorbeeld in opvoeding, gesondheidsdienste, lone', 'arbeidsverhoudinge en arbeidsgeleenthede', 'armoede, honger, behuisingsnood', 'werkloosheid', 'seksualiteit', 'dwelmmiddels, alkohol', 'omgewingsbeheer, ekologie'. Of these, only one was mentioned in more than $1 \%$ of the programmes, namely 'armoede, honger, behuisingsnood', taken together, in 1,3\%. These examples must suffice, although a variety of other questions and approaches led to extremely interesting information as well.

The overall picture was clear and alarming. The public worship of the Afrikaans religious programmes of the SABC was completely separated from church and society, from faith and morals, from doctrine and ethics. It was directed solely at 'religious individuals', with inner-religious needs only, living without church and society. The worship of these programmes celebrated a story almost totally unrelated to the story of the Christian church as well as the story of the particular society in which the listeners and viewers exist. Religion, better: Christianity, as far as the public media go, had been privatised. This left the symbolic public square, the market place of classical democracy, naked. At the same time, it favoured the non-traditional, non-denominational, spectacular and electronic, big-business, success-story, religious groups. It should surprise no-one that the media increasingly treated representatives of such groups as equally representative of religious and Christian opinions than the leaders of traditional main-line denominations and ecumenical bodies, thereby powerfully legitimating this kind of religiosity. In many cases, their impressive style and appeal much more reflected, celebrated and cultivated the (American) style of media-culture than the Christian story. The religion practised and celebrated in public tacitly and uncritically accepted that public life was secular, should be left alone, that religious convictions and values, Christian beliefs and ethos, the Christian story, have no bearing on the market place and in the public square, where the ethos, the direction, the future, the very fabric of public life was formed and informed, debated and decided. 


\section{BIBLIOGRAPHY}

Alberts, L \& Chikane, F (eds) 1991. The road to Rustenburg. The church looking forward to a new South Africa. Cape Town: Struik Christian Books.

Anthonissen, C A 1993. Die geloofwaardigheid van die kerk in die teologie van Dietrich Bonhoeffer. Stellenbosch: University of Stellenbosch, unpublished doctoral thesis.

Barth, K. 1936- $C D=$ Church Dogmatics. Edinburgh: T \& T Clark.

Barth, K 1938. Gotteserkenntnis und Gottesdienst nach reformatorischer Lehre. Zürich: TVZ. (Translated: the knowledge of God and the service of God according to the teaching of the Reformation).

Barth, K 1946. Christengemeinde und Bürgergemeinde. München: Chr. Kaiser Verlag.

Barth, K 1960. The humanity of God. Richmond: John Knox Press.

Barth, K 1963. Evangelical Theology: An introduction. New York: Holt, Rinehart \& Winston.

Barth, K 1981a. The Christian life (CD IV/4). Grand Rapids: Wm B Eerdmans.

Barth, K 1981b. Ethics. New York: Seabury Press.

Berger, T 1985. Lex orandi - lex credendi - lex agendi. ALW 27: 425-432.

Berger, T 1991a. 'Liturgical movement', in Lossky et al (eds), 616-618.

Berger, T 1991b. 'Worship in the ecumenical movement', in Lossky et al (eds), 1107-1112.

Best, T F \& Heller, D (eds) 1995. So we believe, so we pray. Geneva: WCC Publications.

Boesak, A A \& Villa-Vicencio, C (eds), 1986. When prayer makes news. Philadelphia: The Westminster Press.

Bonhoeffer, D 1959. Creation and fall. London: SCM Press.

Botman, H R 1995. 'Dealing with diverisity', in Meeting the future. Christian leadership in South Africa. Buchanan, D \& Hendriks, J (eds). Randburg: Knowledge Resources, 164-172.

Bromiley, G E 1979. Introduction to the theology of Karl Barth. Grand Rapids: Wm B Eerdmans.

Burger, C W et al 1990. Riglyne vir prediking oor vrede. Woord teen die lig III/2. Kaapstad: Lux Verbi.

Burger, C W et al 1993. Riglyne vir prediking oor regverdiging en reg. Woord teen die lig III/3. Kaapstad: Lux Verbi.

Burger, C W et al (forthcoming 1996) Riglyne vir prediking oor die deugde. Woord teen die lig III/4 Kaapstad: Lux Verbi.

Buxton, R F, 1986. 'The sanctification of time', in Davies (ed), 477-478.

Chandlee, H E 1986. 'The liturgical movement', in Davies (ed), 307-314.

Chikane, F 1991. 'Understanding the South African reality', in Alberts \& Chikane, 47-61.

Cilliers, J 1994. God met ons. Kaapstad: Lux Verbi.

Conradie, E 1996. Rus vir die hele aarde. Kaapstad: Lux Verbi.

Crawford, J 1995. 'Worship and the search for Christian unity', in Best and Heller (eds), 28-37.

Cunningham, L 1991. 'And their eyes were opened', Theology Today April, Vol XLVIII1, 2629.

Dalferth, I U 1994. 'Gott und Zeit', in Georgi et al (Hrsg.), 9-34.

Damon, M P 1995. Ekonomiese geregtigheid vir almal. Bellville: UWK, ongepubliseerde Magister-tesis.

Davies, J G (ed) 1986a. A new dictionary of liturgy and worship. London: SCM Press. 
Davies, J G 1986b. 'Secularization and worship', in Davies (ed), 481-484.

De Gruchy, J W 1986a. 'Prayer, politics, and false piety', in Boesak \& Villa-Vicencio (eds), $97-$ 112.

De Gruchy, J W (ed) 1986b. Cry justice! Prayers, meditations and readings from South Africa. London: Collins Liturgical Publications.

De Gruchy, J W 1986c. 'Christian spirituality and social transformation; A South African perspective', in De Gruchy (ed), 23-46.

De Gruchy J W 1994. 'Christian Community', in De Gruchy \& Villa-Vicencio (eds) Theology in Context, 125-138.

De Gruchy J W \& Villa-Vicencio C (eds) 1994. Theology in Context. Cape Town: David Philip.

De Villiers, D E 1978. Die eiesoortigheid van die Christelike moraal, Amsterdam, Rodopi, $175-$ 176.

De Villiers, D E \& Smit, D J 1994. 'Hoe Christene in Suid-Afrika by mekaar verby praat ... Oor vier morele spreekwyses in die Suid-Afrikaanse kerklike konteks' Skrif en kerk, Jrg 15 (2), 228-247.

De Villiers, D E \& Smit, D J 1995. 'Met watter gesag sê u hierdie dinge?' Opmerkings oor kerklike dokumente oor die openbare lewe', Skrif en kerk Jrg 16 (1), 39-56.

De Villiers, D E \& Smit, D J (moet verskyn, 1996) 'Hoekom verskil ons so oor die wil van God? Opmerkings oor Christelike morele oordeelsvorming', Skrif en kerk Jrg 17 (1).

Duchrow, U \& Liedke, G 1989. Shalom. Biblical perspectives on creation, justice \& peace. Geneva: WCC.

Empereur, J L \& Kiesling, C G 1990. The liturgy that does justice. Collegeville, MI: Michael Glazier.

Field, D N 1996. Reformed theology, modernity and the environmental crisis. Cape Town: UCT, unpublished thesis.

Fischer, B 1991. 'Liturgical reforms', in Lossky et al (eds), 618-622.

Fischer, J 1989. 'Wahrnehmung als Proprium und Aufgabe christlicher Ethik', in Glaube als Erkenntnis. Zum Wahrnehmungscharakter des christlichen Glaubens. Chr. Kaiser Verlag: München, 91-118.

Fishburn, J F 1991. 'Moving out of complacency', Theology Today April, Vol XLVIIL/1, 29-33.

Ford, S D 1990. Sins of omission. A Primer on moral indifference. Minneapolis: Fortress Press.

Forrester, D 1995. 'Ecclesiology and ethics: A reformed perspective', The Ecumenical Review, Vol 47/2, 148-154.

Georgi, D, Heimbrock H-G, Moxter, M (Hrsg.) 1994. Religion und Gestaltung der Zeit. Kampen: Pharos Publishing House.

Green, C 1989. Imagining God. San Francisco: Harper \& Row.

Gustafson, J M 1976. Treasure in earthen vessels. Chicago: University of Chicago Press.

Gustafson, J M 1988. Varieties of moral discourse: prophetic, narrative, ethical, and policy. The Stob Lectures of Calvin College and Seminary, Grand Rapids, MI.

Hall, D J 1987. When you pray. Thinking your way into God's world. Valle Forge, PA: Judson Press.

Hauerwas, S 1974. Vision and virtue: Essays in Christian Ethical Reflection. Notre Dame: Fides Publishers.

Hauerwas, S 1985a. Against the nations. War and survival in a liberal society. Minneapolis: Winston Press-Seabury Press. 
Hauerwas, S 1985b. 'Remembering as a moral task', Against the nations, 61-90

Hauerwas, S 1995a. In good company. The church as polis. Notre Dame; The University of Notre Dame Press.

Hauerwas, S 1995b. 'The liturgical shape of the Christian life: teaching Christian ethics as worship', in In good company, 153-168.

Hauerwas, S \& Willimon, W H 1989. Resident aliens. Nashville: Abingdon Press.

Heimbrock, H-G 1994. 'Gottesdienst: Gestaltung der Zeit in symbolischem Handeln', in Georgi et al (Hrsg.), 77-91.

Hendriks, H J 1995a. 'South African denominational growth and decline 1911-1991', JTSA 91, 35-58.

Hendriks, H J 1995b. 'Facing the facts', Meeting the future. Christian leadership in South Africa. Buchanan, D \& Hendriks, J (eds). Randburg: Knowledge Resources, 17-32

Hendriks, H J 1996. 'Kerkspieël IV en NGK statistiek in die wyer raamwerk van die perspektief van die Suid-Afrikaanse bevolkingsensusse 1911-1991', NGTT 37/1, 138-145.

Horn, J N J 1987. Teologie of Politiek? 'n Sistematies-Teologiese analise van die wisselwerking tussen teologie en politiek by Karl Barth, met besondere verwysing na die jare 19331946. Bellville: UWK. Ongepubliseerde D.Th-tesis.

Huber, W 1984. Erinnerung, Erfahrung, Erwartung. Die Ungleichzeitigkeit der Religion und die Aufgabe theologischer Ethik, in: Chr. Link (Hrsg.), Die Erfahrung der Zeit. Stuttgart: Klett-Cotta, 321-336.

Huber, W 1986. 'Ohne Erinnerung, keine Befreiung', Brïcken der Verständigung, E Raiser, H Lenhard u. B Homeyer (Hrsg.). Gütersloh: Gütersloher Verlagshaus, Gerd Mohn, 11-14

Huber, W 1987. 'Versöhnung beginnt, wo Verdrängung endet', Deutscher Evangelischer Kirchentag, 11-14;

Huber, W 1996. 'Christliche Freiheit in der freiheitlichen Geselischaft', Evangelische Theologie 56. Jg., Heft 2, 99-116.

Huber, W, Ritschl, D \& Sundermeier, T 1986. Ökumenische Theologie. München: Chr. Kaiser Verlag.

Hütter, R 1993. Evangelische Ethik als kirchliches Zeugnis. Neukirchen-Vluyn: Neukirchener Verlag.

Jennings, T W Jr 1982. Life as worship: Prayer and praise in Jesus' name. Grand Rapids: Wm B Eerdmans.

Jennings, T W 1988. The liturgy of liberation. Nashville: Abingdon.

Jngel, E 1977 Gott als Geheimnis der Welt. Tbingen: J C B Mohr (Paul Siebech), translated as God the mystery of the world. Edinburgh: T \& T Clark, 1983.

Jones, C, Wainwright, G, \& Yarnold, E (eds) 1978. The study of liturgy. Oxford: Oxford University Press.

Jones, L G 1990. Transformed judgment. Notre Dame, IN: University of Notre Dame Press.

Jones, L G 1995. Embodying forgiveness. Wm B Eerdmans: Grand Rapids.

Jörns K-P 1988a. Lex orandi - lex credendi - lex convivendi. Paradigma für Kirche und Theologie, in H. Riehm (Hg.), Freude am Gottesdienst. Festschrift für F Schulz zum 70. Geburtstag, Heidelberg 1988.

Jörns K-P 1988b. Lex orandi - lex credendi - lex convivendi [umgearbeitet] in Der Lebensbezug des Gottesdienstes. Studien zu seinem kirchlichen und kulturellen Kontext. München: Chr. Kaiser, 12-22. 
Koopman, N N (onvoltooid, 1996/1997) Deugde of dade? Bellville: UWK, doktorale tesis.

Lange, E 1980. Sprachschule für die Freiheit. München: Kaiser Verlag.

Lathrop, G 1995. 'Knowing something a little: On the role of the lex orandi in the search for Christian unity', in Best and Heller (eds), 38-48.

Lehmann, P 1985. 'Praying and doing justly', Reformed Liturgy and Music XVX:2, 79.

Leith, J H 1988. The Reformed imperative. Philadelphia: Westminster Press.

Lossky, $\mathrm{N}$ et al (eds) 1991. Dictionary of the ecumenical movement. Geneva: WCC Publications.

Luz, U 1985. Das Evangelium nach Matthäus. 1. Teilband. Neukirchen-Vluyn-Neukirchener Verlag.

Maxwell, W D 1986. 'Reformed worship', in Davies (ed), 458-460.

McClendon, J W 1989. Ethics: Systematic theology. Nashville: Abingdon Press.

McKim, D (ed) 1992. Major themes in the Reformed tradition. Grand Rapids: Wm B Eerdmans.

Meilaender, G, 1986. 'Virtue in comtemporary religious thought', in Neuhaus (ed), 7-29.

Meyendorff, P 1991. 'Liturgy', in Lossky et al (eds), 6623-626.

Mouton, A E J 1995. Reading a New Testament document ethically: Towards an accountable use of Scripture in Christian ethics, through analysing the transformative potential of the Ephesians Epistle. Bellville: UWC, unpublished doctoral thesis.

Müller, B A \& Smit, D J 1991 Godsdiens in die openbaar. Tendense in die Afrikaanse godsdiensprogramme van die SAUK, NGTT 1991/4, 652-665

Müller, B A \& Smit, D J 1994. 'Public worship - a tale of two stories', The relevance of theology for the nineties, Mouton, J \& Lategan, B C (eds), Pretoria, HSRC, 385-408.

Müller, J 1988. Die erediens as fees. Pretoria: NGKB.

Neuhaus, R J (ed) 1986. Virtue - public and private. Grand Rapids: Wm B Eerdmans

Newton, D 1986. 'Sociology of worship', in Davies (ed), 493-497.

Niebuhr, H R 1951. Christ and culture. New York: Harper \& Row.

Niles, D P (ed) 1992. Between the flood and the rainbow. Geneva: WCC Publications.

Olson, D T 1991. 'Which comes first, justice or worship?' Theology Today April, Vol XLVIII/1, 22-26.

Petersen, R M 1995. Time, resistance and reconstruction: Rethinking Kairos theology. Chicago: University of Chicago, unpublised doctoral thesis.

Phillips, A P 1996 Die Nagmaal as paradigma vir die Christelike etos. Bellville: UWK, ongepubliseerde doktorale tesis.

Ramsey, P 1979. 'Liturgy and ethics', JREthics 7/2, 139ff.

Richardson, R N 1986. Christian community and ethics: critical reflections on the nature and function of the church in the ethics of Stanley Hauerwas. Pietermaritzburg. Doctoral thesis.

Richardson, R N 1994. 'Ethics of character and community', in Villa-Vicencio \& De Gruchy (eds), Doing Ethics in Context, 89-101.

Ritschl, D 1987. The logic of theology. Philadelphia: Fortress Press.

Saliers, D E 1994. Worship as theology. Foretaste of divine glory. Nashville, TE: Abingdon Press.

Schaeffler, R 1988. Kleine Sprachlehre des Gebets. Trier: Johannes-Verlag.

Schobert, I 1992. Erinnerung als Praxis des Glaubens. München: Chr. Kaiser Verlag.

Schuurman, D (forthcoming, 1996/1997) Protestant vocation after Christendom. Grand Rapids: Wm B Eerdmans. 
Searle, M (ed) 1980. Liturgy and social justice. Collegeville:The Liturgical Press.

Smit, D J 1995. 'Church and civil society?' Unpublished paper, EFSA-Conference on Church and Development, September.

Smit, D J 1996a. Reformed ethics and 'economy as a matter of faith', NGTT September.

Smit, D J 1996b 'Om nie te vergeet nie (Deut 6:1-25)', in Burger et al.

Smit, D J 1996c 'Oor die kerk as 'n unieke samelewingsverband', Tydskrif vir Geesteswetenskappe, Junie.

Spiegel, Y 1994. 'Religion und Zeitstrukturierung', in Georgi et al (Hrsg.), 136-146.

Strauss, de W (onvoltooid, 1996/1997) ' $n$ Kerk om in te glo. Bellville: UWK, doktorale tesis.

Streib, H 1994. 'Erzählte Zeit als Ermöglichung von Identität', in Georgi et al (Hrsg.), 181-198.

Thiemann, 1991. 'Worship and public responsibility', in Constructing a public theology. The church in a pluralistic culture. Louisville, KE: Westminster/John Knox Press, 112-125.

Tödt, H-E 1977 'Versuch zu einer Theorie ethischer Urteilsfindung', ZEE 21, 1977, 81-93;

Tödt, H-E 1988a. Perspektiven theologischer Ethik. München: Chr. Kaiser.

Tödt, H-E 1988b 'Versuch einer ethischen Theorie sittlicher Urteilsfindung, in Perspektiven theologischer Ethik, 21-48.

Tödt, H-E 1988c 'Die Zeitmodi in ihrer Bedeutung für die sittliche Urteilsbildung', in Perspektiven theologischer Ethik, 49-85.

URCSA 1994, Kerkorde en reglemente van die Algemene Sinode van die Verenigende Gereformeerde Kerk in Suider-Afrika, Vasgestel deur die Eerste Algemene Sinode te Belhar.

Villa-Vicencio, C \& De Gruchy, J W (eds) 1994. Doing ethics in context: South African perspectives. Cape Town: David Philip.

Volf, M 1993. 'Worship as adoration and action: Reflections on a Christian way of being-in-theworld', Worship: Adoration and action, D Carson (ed). Grand Rapids: Baker, 203-211.

Vosloo, R R 1994. Verhaal en moraal: 'n Kritiese ondersoek na die narratiewe etiek van Stanley Hauerwas. Bellville: UWK, ongepubliseerde doktorale tesis.

Wainwright, G 1980. Doxology. The praise of God in worship, doctrine, and life. New York: Oxford University Press.

Wainwright, G 1981. 'Towards God', USQR.Vol XXXVI: 13-26.

Wainwright, G 1982. 'Der Gottesdienst als Locus Theologicus, oder: Der Gottesdienst als Quelle und Thema der Theologie'. KuD 1982, 4: 248-257.

Wainwright, G 1983. The ecumenical moment. Grand Rapids: Wm B Eerdmans.

Wainwright, G 1986a. 'Ad majorem Dei gloriam', in McKim, D K (ed), How Karl Barth changed my mind, Grand Rapids, Wm B Eerdmans, 178-181.

Wainwright, G 1986b. 'Theology of worship', in Davies (ed), 505-507.

Wainwright, G 1991. 'Renewing worship: the recovery of classical patterns', Theol Today April, Vol XLVIII/1, 45-55.

Wainwright, G 1992. 'Trinitarian worship', in Kimel, A F (ed), Speaking the Christian God. Grand Rapids: Wm B Eerdmans, 209-221.

Wannenwetsch, B 1996. 'The political worship of the church: A critical and empowering practice', Modern Theology Vol 12/3, 269-299.

Westland, L 1985. Eredienst en maatschappij. Een onderzoek naar de visies van A A van Ruler, de prof dr $G$ van der Leeuw-stichting and de beweging Christenen voor het Socialisme. 'S-Gravenhage: Uitgeverij Boekencentrum B V. 
White, J F 1991. Introduction to Christian worship. Nashville:Abingdon Press.

Willimon, W H 1983. The service of God. How worship and ethics are related. Nashville: Abingdon Press.

Witvliet, T 1986. 'Liberation and worship', in Davies (ed), 302-305.

Wolterstorff, N 1983. Until justice and peace embrace. Grand Rapids: Wm B Eerdmans.

Wolterstorff, N 1989. 'Liturgy, justice, and holiness', The Reformed Journal, December, 12-20.

Wolterstorff, N 1991. 'Justice as a condition of authentic liturgy', Theology Today, April, Vol $\mathrm{XILVIII/1,}$

Wolterstorff, N 1992a. 'The Reformed liturgy', in McKim (ed), 273-304.

Wolterstorf, N 1992b. 'Worship and justice', in McKim (ed), 311-318.

Wuthnow, R 1993. Christianity in the 21st century. Reflections on the challenges ahead. Oxford: OUP.

Wuthnow, R 1995. Learning to care. Elementary kindness in a culture of indifference.

Yoder, J H 1991. 'Sacrament as social process: Christ the transformer of culture', Theology Today, Vol XIVIII/1, 33-45.

Yoder, J H 1994. The royal priesthood. Grand Rapids: Wm B Eerdmans.

Zerfaß, H 1988. Erzhlter Glaube - erzhlende Kirche. Freiburg: Herder. 